DOI https://doi.org/10.30525/978-9934-26-046-9-38

\title{
ВОСКОПОДІБНІ КОМПОНЕНТИ РОСЛИННОГО ПОХОДЖЕННЯ ЯК ФУНКЦІОНАЛЬНІ ДОБАВКИ КОСМЕТИЧНИХ ПРОДУКТІВ
}

\author{
Руднєва Л. Л. \\ викладач кафедри технології природних і синтетичних полімерів, \\ жирів та харчової продукції \\ ДВНЗ «Украӥнський державний хіміко-технологічний університет» \\ м. Дніпро, Украӥна \\ Андріянова М. В. \\ кандидат хімічних наук, \\ доцент кафедри технології природних і синтетичних полімерів, \\ жирів та харчової продукиії \\ ДВНЗ «Украӥнський державний хіміко-технологічний університет» \\ м. Дніпро, Украӥна

\section{Бухкало С. I.} \\ кандидат технічних наук, доцент, \\ професор кафедри інтегрованих технологій, процесів і апаратів \\ Національний технічний університет \\ «Харківський політехнічний інститут» \\ м. Харків, Україна
}

На сьогоднішній день воски широко використовуються в різних галузях промисловості.

Завдяки своїй низькій вартості широко використовується парафін, який отримують в результаті дистиляції нафтопродуктів. Проте він має низькі показники якості в харчовій та косметичній галузі, може виявляти шкідливу дію на організм людини.

Також у великій кількості використовують бджолиний віск, який має високі показники якості, але часто може бути алергенним.

Найприйнятнішими у використані є рослинні воски. Найвідоміші $з$ них карнаубський таканделільський мають найвищі показники якості, але і найвищу вартість.

Недоступність використання натуральних якісних восків зумовила пошук їх альтернативи. Одержані воскоподібні компоненти 158 
3 рослинної сировини, а саме, з соняшникового лушпиння, мають показники, які дуже близькі до найбільш вживаних у господарстві(табл. 1).

Таблиця 1

Фізико-хімічні характеристики восків [1]

\begin{tabular}{|c|c|c|c|c|}
\hline Показник & $\begin{array}{c}\text { Карна- } \\
\text { убський } \\
\text { віск }\end{array}$ & Парафін & $\begin{array}{c}\text { Бджолиний } \\
\text { віск }\end{array}$ & $\begin{array}{c}\text { Воско- } \\
\text { подібні } \\
\text { компоненти }\end{array}$ \\
\hline $\begin{array}{c}\text { Кислотне число, } \\
\text { мг КОН/г }\end{array}$ & $1-12$ & - & $18-22$ & $2-17$ \\
\hline $\begin{array}{c}\text { Иодне число, \% } \\
\mathrm{I}_{2}\end{array}$ & $5-14,5$ & - & $7-11$ & $11,0-12,4$ \\
\hline $\begin{array}{c}\text { Ефірне число, } \\
\text { мг КОН }\end{array}$ & $75-86$ & - & $87-107$ & $98-108$ \\
\hline $\begin{array}{c}\text { Температура } \\
\text { плавлення, }{ }^{\circ} \mathrm{C}\end{array}$ & $80-90$ & $45-65$ & $60-70$ & $65-73$ \\
\hline $\begin{array}{c}\text { Температура } \\
\text { кристалізації, }{ }^{\circ} \mathrm{C}\end{array}$ & $86-90$ & $50-56$ & $60-70$ & $70-74$ \\
\hline $\begin{array}{c}\text { Густина, г/см }{ }^{3} \\
\text { Показник }\end{array}$ & $0,960-$ & 0,915 & $0,950-0,970$ & $0,920-0,960$ \\
\hline заломлення, & 1,4752 & 1,4420 & 1,4467 & $\begin{array}{c}1,4410- \\
1,4500\end{array}$ \\
\hline
\end{tabular}

Були проведені дослідження використання воскоподібних компонентів соняшникового лушпиння, як більш якісних та дешевих, в косметичній промисловості, а саме, у складі гігієнічного бальзаму для губ.

Гігієнічний бальзам для губ - косметичний засіб, один з різновидів губної помади. Призначений для захисту ніжної шкіри губ від несприятливих впливів навколишнього середовища.Зазвичай у складі промислової гігієнічних бальзамів для губ на першому-другому місці йде парафін, вазелін або щось з цієї серії - дешева заміна натуральним оліям або жирам. Він не зволожує і не живить губи, а створює на поверхні плівку, яка поступово з'їдається. До складу гігієнічних бальзамів для губ можуть входити натуральні рослині воски (карнаубський, канделільський та ін.), які значно підвищують корисні властивості бальзамів для губ. Недоліком таких гігієнічних бальзамів для губ є висока ціна. 
Тому було проведено дослідження використання одержаних воскоподібних компонентів з соняшникового лушпиння в рецептурі гігієнічного бальзаму для губ, замінюючи парафін та карнаубський віск.

Одержаний гігієнічний бальзам для губ, до складу якого входять воскоподібні компоненти соняшникового лушпиння, мають світлий колір, приємний аромат та однорідну задовільну консистенцію. Легко та рівномірно наноситься на губи. Відсутнє відчуття плівки на губах, отже губи дихають. Добре змішується з різними компонентами, створює стабільну структуру та не має шкідливого впливу. $€$ більш дешевим ніж імпортні рослинні воски.

Задля визначення доцільності використання воскоподібних компонентів соняшникового лушпиння, як компоненту гігієнічних бальзамів для губ, була проведена порівняльна оцінка показників якості бальзамів для губ (табл. 2), згідно з [2].

Таблиця 2

\section{Порівняльна характеристика зразків гігієнічного бальзаму для губ}

\begin{tabular}{|c|c|c|}
\hline Показник & Норма & Бальзам $^{*}$ \\
\hline Зовнішній вигляд & $\begin{array}{c}\text { Поверхня гладка, однорідна, } \\
\text { рівномірно забарвлена }\end{array}$ \\
\hline Колір & Властивий даному виду виробу \\
\hline Запах & $\begin{array}{c}\text { Приємний, властивий даному } \\
\text { виду виробу }\end{array}$ \\
\hline Мазок & \multicolumn{2}{|c|}{ Рівний, однорідний } \\
\hline $\begin{array}{c}\text { Температура } \\
\text { краплепадіння, }{ }^{\circ} \mathrm{C}\end{array}$ & $55-80$ & 66,4 \\
\hline Кислотне число, мг КОН/г & не більше 15 & 4,3 \\
\hline $\begin{array}{c}\text { Карбонільне число, } \\
\text { мг КОН/г }\end{array}$ & не більше 8 & 3,5 \\
\hline
\end{tabular}

*Бальзам, до складу якого входять воскоподібні компоненти соняшникового лушииння

В результаті порівняння видно, що зразок на основі воскоподібних компонентів соняшникового лушпиння має показники, відповідні до [2]. Порівняно з нормою, одержаний зразок має дещо більші показники температури краплепадіння та кислотного числа. Це обумовлено тим, що воскоподібні компоненти соняшникового лушпиння, які входять до складу гігієнічних бальзамів для губ, мають у своїй хімічній структурі високомолекулярні жирні кислоти та високомолекулярні спирти, які мають більшу температуру плавлення. 


\section{Література:}

1. Руднева Л.Л. Исследование процессов утилизации растительных восков. Материаль VI Международного научно-технического Симпозиума "Современные энерго- и ресурсосберегающие технологии СЭТТ-2017», Международного научно-технического Форума «Первые международные Косыгинские чтения. Т. 2. Москва. ФГБОУ ВО «РГУ им. А.Н. Косыгина». 2017. С. 178-181.

2. ДСТУ 4774:2007 «Вироби косметичні для макіяжу на жировосковій основі. Загальні технічні умови». 2007. 4 с.

DOI https://doi.org/10.30525/978-9934-26-046-9-39

\section{ІННОВАЦІЙНІ МЕТОДИ ЗБАГАЧЕННЯ БЕРЕЗОВОГО СОКУ}

\section{Суткович Т. Ю.}

кандидат технічних наук, доцент,

доцент кафедри технологій харчових виробництв

і ресторанного господарства

ВНЗ Укоопспілки «Полтавський університет економіки і торгівлі м. Полтава, Украӥна

\section{Палвашова Г. I.}

кандидат технічних наук, дочент кафедри біоінженерії $і$ води Одеська начіональна академія харчових технологій м. Одеса, Украӥна

\section{Положишникова Л. О.}

кандидат технічних наук, доцент кафедри технологій харчових виробниџтв

і ресторанного господарства

ВНЗ Укоопспілки «Полтавський університет економіки і торгівлі» м. Полтава, Украӥна

Несприятливі фактори зовнішнього середовища впливають на організм людини. Зміцнення здоров'я населення може відбуватися шляхом включення в раціон продуктів харчування, що має виражений профілактичний і лікувальний вплив [1, с. 7]. 